REPORTS OF MORPHOLOGY
Official Journal of the Scientific Society of Anatomists,
Histologists, Embryologists and Topographic Anatomists
of Ukraine
journal homepage: https://morphology-journal.com

\title{
Features of the structural and functional parameters of the liver in experimental steatohepatitis and its correction in obese rats
}

\section{Pivtorak K.V.}

National Pirogov Memorial Medical University, Vinnytsya, Ukraine

\section{ARTICLE INFO}

Received: 28 November, 2018

Accepted: 15 January, 2019

UDC: $616.36-003.826: 611.36 .068$ :

615.036 .8

\section{CORRESPONDING AUTHOR}

e-mail: ek3727@gmail.com Pivtorak K.V.

\begin{abstract}
Summary. The improvement of the pharmacological strategy of non-alcoholic fatty liver disease is based on the study of the effect of pharmaceutical preparations on the structure and function of the liver. The pathogenesis of steatohepatitis is complex and multifactorial, mainly involving genetic, metabolic and environmental factors. The purpose of the study was to characterize the structural and functional parameters of the liver when using the biologically active compound Angiolin for the correction of experimental steatohepatitis. An experimental study was performed on 110 sexually mature white male rats weighing 180-220 grams, which were kept on a standard diet of vivarium. All animals were divided into two groups: control (30 intact animals) and experimental ( 80 animals). A model of non-alcoholic steatohepatitis was created for all animals of the experimental group. They were kept on a hypercaloric diet with a high fat and high cholesterol content for 8 weeks. After that, part of the animals (10 rats) was withdrawn from the experiment by intrapleural administration of sodium thiopental (50 $\mathrm{mg} / \mathrm{kg}$ ) and the necessary biochemical and morphological studies were performed. Part of the animals (30 rats) was continued to be kept on a high-fat diet for 4 weeks and the biologically active compound Angiolin was administered (20 rats), and RingsLocke solutions were administered to 10 rats. After the creation of the model, the other animals of the experimental group (40 rats) were transferred to a full-fledged standard semi-synthetic starch-casein diet, and the biologically active compound Angiolin was administered for 20 rats and Ringer-Locke solution for another 20 rats for 4 weeks. Macroscopic evaluation and description of the liver of animals was carried out after withdrawal under thiopental anesthesia. Statistical analysis of the results was carried out using the program "STATISTICA 8" using parametric and non-parametric methods for assessing the results. It was found that the use of the biologically active compound Angiolin once a day for 30 days can reduce cytolysis syndrome (reduce biochemical parameters such as ALT, AST, gamma-glutamyl transpeptidase), reduce cholestasis syndrome (decrease in alkaline phosphatase level), and normalize liver function, improves the morphological state of hepatocytes, which indicates the normalization of the structural and functional state of the liver.

Key words: liver disease, steatohepatitis, modelling, morphology, correction.
\end{abstract}

\section{Introduction}

In recent years, the global burden of obesity and diabetes has led to a parallel increase in other metabolic complications, such as non-alcoholic fatty liver disease (NAFLD). NAFLD is the most common type of chronic liver injury in many countries [8, 17]. NAFLD includes a spectrum of syndromes ranging from simple steatosis, nonalcoholic steatohepatitis to fibrosis, cirrhosis and hepatocellular carcinoma [27]. The overall prevalence of NAFLD is 15$40 \%$ in Western countries and $9-40 \%$ in Asian populations. Over the last 15 years, NAFLD has grown dramatically in parallel with two major epidemics worldwide - obesity and type 2 diabetes [9]. Mortality in patients with NAFLD is significantly higher than in a similar age population [14]. Simple steatosis tends to be stable, but steatohepatitis can progress to cirrhosis [10]. The World Gastroenterology Organization (WGO) has recently published a number of comprehensive guidelines for the evaluation and treatment of NAFLD [13], with an emphasis on the distinction between simple steatosis and non-alcoholic steatohepatitis (NASH). Ukrainian scientists have established that the course of 
nonalcoholic steatohepatitis with secondary arterial hypertension is characterized by higher histological activity, which leads to the progression of fibrotic changes [11].

In the last decade of the 20th century, the theory of "two hits" was the most proven theory of NASH pathogenesis. Currently, this theory is replaced by the theory of "multiple hits" [16]. Genetic factors interact with metabolic and environmental factors, contributing to the accumulation of fat in hepatocytes, and consistently cause inflammation, cell death and fibrosis [3]. Recently, the cause and effect of insulin resistance in the development of NASH has been called into question, since NAFLD is often preceded and more predicted by the development of obesity, diabetes, dyslipidemia, arterial hypertension and cardiovascular disease [15].

Numerous pharmacological strategies have been tested in clinical trials for NAFLD therapy, and according to the aforementioned theory of NAFLD pathogenesis, different classes of drugs can be identified: antidiabetic drugs, antioxidants, prebiotics, drugs with anti-inflammatory, membranoprotective.

In order to prevent cardiovascular complications, it is imperative for these patients to treat cardiovascular risk factors, such as dyslipidemia, hypertension, and endothelial dysfunction [7].

Created a new original drug with endothelioprotective action by synthesis of the active substance (S) -2,6diaminohexanoic acid 3-methyl-1,2,4-triazolo-5-thioacetate (working name Angiolin), which combines fragments of thiotriazolin molecules and L-lysine of escinate and has high anti-ischemic, cardioprotective, neuroprotective, antioxidant and anti-inflammatory properties [5]. Intravenous administration of angiolin to animals with myocardial ischemia led to normalization of the ratio of thiol-disulfide system and nitric oxide system in the myocardium, and in rats with experimental chronic heart failure led to increased activity of endothelial NO-synthase, increased glutathione reductase activity of endothelial cells [18]. The use of the biologically active compound Angiolin in the complex treatment of NAFLD is rational in terms of its effect on metabolic processes occurring in the liver and for the purpose of correction of endothelial dysfunction, prevention of cardiovascular complications.

The aim - to characterize the structural and functional parameters of the liver in experimental steatohepatitis correction by biologically active compound Angiolin.

\section{Materials and methods}

Experimental studies were conducted on 110 white, nonlinear, mature males weighing 180-200 g. Permission was obtained from the Bioethics Commission of National Pirogov Memorial Medical University, Vinnytsya (protocol №5 of March 27,2014 ) to conduct the experiment. Animal retention and experiments were conducted in accordance with the provisions of the "European Convention for the Protection of Vertebrate Animals Used for Experiments and Other
Scientific Purposes" (Strasbourg, 2005), and the "General Ethical Principles for Animal Experiments", adopted by the Fifth National Congress on Bioethics (Kyiv , 2013). Prior to the start of the experiments, the animals were quarantined for 10 days. During this period, the animals received a complete standard semi-synthetic starch-casein diet. Subsequently, the animals were divided into 2 groups: control - 30 intact animals that continued to be on the same diet under similar conditions with the animals of the experimental group, and experimental - 80 rats, which were created by the NASH model, for which for 8 weeks kept on a hypercaloric diet with high fat and high cholesterol containing about 30\% fat (mainly saturated lipids) by adding cholesterol (obtained by mixing $2 \mathrm{~g}$ of cholesterol and $10 \mathrm{~g}$ of lard with $88 \mathrm{~g}$ of pellets of a normal balanced diet) [12, 28].

After the creation of the NASH model, the animals of the experimental group were further divided into five groups. Animals of the first experimental group (10 rats) were removed from the experiment and the necessary biochemical and morphological studies were performed.

Animals of the second experimental group (20 rats) were continued to be maintained on a high-fat diet (HFD), but an additional $50 \mathrm{mg} / \mathrm{kg}$ of Angiolin was administered intravenously over 4 weeks (HFD), but intraperitoneally.

Animals of the third experimental group (10 rats) also continued to be kept on HFD, but for an additional 30 days only Ringer-Locke solution $(25 \mathrm{ml} / \mathrm{kg}$ ) was intraperitoneally. Animals of the fourth experimental experimental group (20 rats) after the creation of the NASH model received a complete standard semisynthetic starch-casein diet and for 4 weeks was administered an additional 30 days RingerLocke solution $(25 \mathrm{ml} / \mathrm{kg})$ intraperitoneally. The animals of the fifth experimental group (20 rats) after the creation of the $\mathrm{NASH}$ model in addition to a full standard semisynthetic starch-casein diet for 4 weeks was administered a biologically active compound Angiolin at a dose of $50 \mathrm{mg}$ per kg body weight (adjusted by Ringer-Locke solution) 25 $\mathrm{mg} / \mathrm{kg}$.

During the experiment, regular weekly weighing of the animals was performed to monitor the dynamics of the change in body weight of rats in grams (g). Body length (from nose to anus) was determined in centimeters $(\mathrm{cm})$ to all rats. Body weight and body length were used to determine body mass index (BMI). BMI was calculated by the formula $[2,19]$ : BMI (g/cm2) = body weight / (body length) 2 .

All animals under thiopental anesthesia $(40 \mathrm{mg} / \mathrm{kg}$ ) were sampled for biochemical study and liver tissue samples for morphological examination. The liver was weighed on an analytical balance. The relative weight of the liver was calculated by the formula: (liver weight / body weight) ${ }^{*} 100 \%$.

After centrifugation, the following standard serum methods were used to determine the activity of enzyme markers of cytolysis - alanine aminotransferase (ALT), aspartate aminotransferase (AST) using the Wrightman and Frenkel colorimetric method, and cholestasis markers - alkaline phosphatase (ALPL) enzyme n-nitrophenilphosphate using 
calorimetrimetry by Bodansky. Bilirubin content was determined by reaction with diazotized sulfanilic acid in the presence of a caffeine reagent (Endrashik method) according to the Bilirubin kit (Filitis-Diagnostics, Ukraine).

Macroscopic evaluation and description of the tissues of the liver of animals were performed after their extraction. To detect morphological abnormalities, tissue fragments of the left lobe of the liver were taken for histological examination, followed by their fixation in $10 \%$ neutral formalin neutral solution and paraffin filling according to the conventional method. The morphological condition of the liver in the experiment was evaluated on the basis of histological examination by staining drugs with hematoxylin, eosin, sudan III [4]. The micropreparations were examined using an SEO SSCAN light microscope and photo-documented using a Vision CCD Camera with histological specimens.

For electron microscopic examination, liver slices were fixed in $2.5 \%$ glutaraldehyde solution on $0.1 \mathrm{~g}$ phosphate buffer and fixed in $1 \%$ osmium tetroxide solution on phosphate buffer, $1 \%$ tannic acid solution, dehydrated in an alcohol battery, and a growing concentration of alcohol, in mixtures of acetone and epon and poured into a mixture of epon and araldite. The morphological structures were contrasted in the process of dehydration of the material with a saturated solution of uranyl acetate, and in sections with lead citrate. Sections $40-60 \mathrm{~nm}$ thick, obtained on a UMTP. 7 ultramicrotome, and were examined in a PEM-125 K. electron microscope.

Statistical analysis of the obtained results was performed using the licensed program "STATISTICA 8" by Statsoft, using parametric and non-parametric methods of estimation of the obtained results. Data are presented in the form of median (Me) and interquartile range (Q1-Q3). The normality of distribution was checked using the Kolmogorov-Smirnov test. The non-parametric Mann-Whitney $U$ rank test was used for the asymmetric distribution. The statistical significance of the difference between the comparative values was considered significant at $p<0.05$.

\section{Results}

Anthropometric indices of experimental rats significantly changed during the experiment. The use of HFD for 60 days resulted in an increase in body weight of 1.66 times, and after 90 days - of 1.87 times, with the body mass index (BMI) increasing by 1.32 and 1.39 times, respectively. Liver weight reached $10.91 \mathrm{~g}$ after model creation, and after 12 months it reached $12.68 \mathrm{~g}$. Relative liver weight was increased by $12.15 \%$ and $15.06 \%$, respectively, compared to the control. The use of Angiolin - (S)-2,6-diaminohexanoic acid 3-methyl1,2,4-triazolyl-5-thioacetate, after the creation of a model of $\mathrm{NASH}$ without abrogation of HFD resulted in a decrease in the body weight of rats by $15.12 \%$, BMI - by $6.52 \%$, liver weight by $21.61 \%$, relative liver weight by $7.65 \%$. The use of a standard semi-synthetic starch-casein diet after the creation of the NASH model led to a decrease in the body weight of rats by only $14.55 \%$, BMI $-6.33 \%$, liver weight $-19.01 \%$,

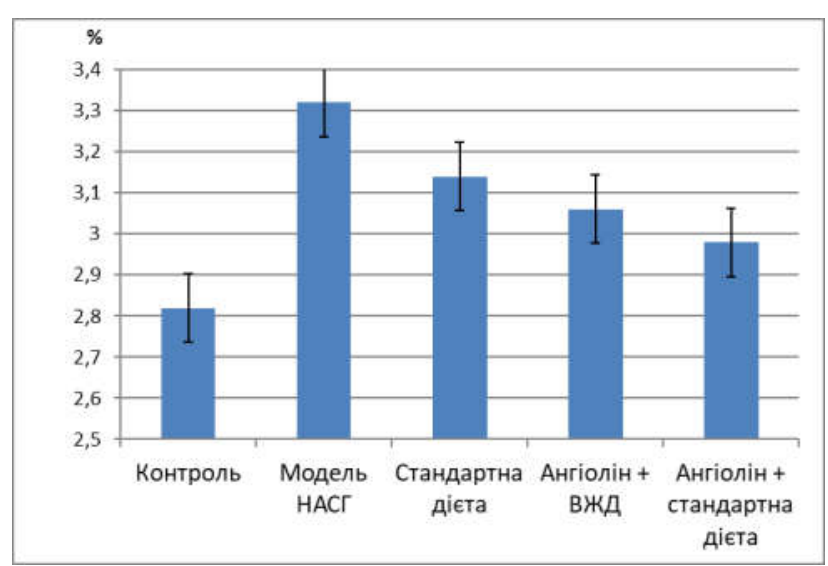

Fig. 1. Changes in the relative weight of the liver after the creation of a model of non-alcoholic steatohepatitis in rats and its correction.

relative liver weight $-5.21 \%$.

The use of the biologically active compound Angiolin at a dose of $50 \mathrm{mg}$ per $\mathrm{kg}$ body weight after the creation of the $\mathrm{NASH}$ model in addition to a full standard semi-synthetic starch-casein diet for 4 weeks showed statistically significant results. The body weight of experimental animals was lower by $18.67 \%$, BMI - by $10.02 \%$, liver weight - by $26.97 \%$, relative liver weight - by $10.24 \%$ compared with rats without treatment (Fig. 1). Macroscopically, the liver was enlarged, yellow with a bold gloss on the incision.

The obtained experimental results showed that the test compound Angiolin has a hepatoprotective effect. A study of the intensity of cytolysis syndrome in rats with the correction of the NASH experimental model showed that there was less ALT activity using Angiolin along (by $20.52 \%$, $p<0.05$ ) and Angiolin with the standard semi-synthetic starch-casein diet (by $33.61 \%$ p <0.05) compared with the activity of untreated animals with the NASH model. Gammaglutamyltranspeptidase activity was also lower using the compound compared to non-treated animals: by $20.19 \%$ with Angiolin $(p<0.05)$ and by $32.86 \%$ with Angiolin along with standard semi-synthetic starch-casein diet. The activity of AST did not come close to the control values using the compound, however, this figure was statistically different by $28.61 \%(p<0.05)$ after treatment with angiolin together with the standard semi-synthetic starch-casein diet compared to untreated animals. Increasing biochemical markers of liver tissue damage on the background of insulin resistance indicates the presence of structural and functional changes in hepatocytes with the development of cytolysis and cholestasis syndromes.

Since the biochemical markers of cholestasis syndrome are the level of total, direct bilirubin and ALPL activity, we evaluated the level of these indicators to assess the effectiveness of angiolin. The indicator that most clearly presented cholestasis syndrome in rats with the NAFLD model was ALPL activity, which in untreated animals was $30.82 \%$ higher $(p<0.05)$ compared to the intact group. Less activity of ALPL compared with the untreated group was with the administration of Angiolin (18.04\%, p<0.05) and with the 
administration of Angiolin along with the standard semisynthetic starch-casein diet $(29.79 \%, p<0.05)$. In the study of total and direct bilirubin content, it was noted that after NASH modeling, the total bilirubin level increased by $20.46 \%$ and direct bilirubin by $8.19 \%$. Increased total, direct bilirubin and LF activity confirms the development of cholestasis syndrome with impaired biliary function of the liver with impaired bile duct formation and damage to small bile ducts. Using Angiolin, the levels of these indicators were statistically significantly lower: by $10.74 \%$ and by $5.43 \%$, respectively.

A histomorphological study of the liver of intact rats revealed a typical structure of the liver lobules. The boundaries of the liver lobules were determined only by the location of the interspecies vessels and bile ducts constituting the "triads". Each triad has an interparticle artery, an interparticle vein and a bile duct. Round-shaped hepatocytes with eosinophilic cytoplasm and basophilic nucleus were found. Diploid hepatocytes were detected in places in the liver. The liver lobes consisted of well-defined beams radially diverging from the central vein. Sinusoids, moderately filled with red blood cells, lay between the beams. The portal tracts were medium in size. The diameter of the veins was much larger than the arteries. A small number of stellate cells were detected. Between the lobes was the connective tissue. The cytoplasm had no pronounced vacuolation.

Conducted morphological study of the liver of rats after 60 days of feeding of HFD revealed a significant accumulation of lipids in hepatocytes, which caused cell hypertrophy, narrowing of the sinus lumines.

There was a plethora of central veins. Fatty hepatocyte dystrophy had the appearance of microvesicular and macrovascular vacuolation. A significant increase in hepatocyte size was found compared to the control group of animals. The filling of the cytoplasm with fatty drops caused deformation of the nuclei and displacement of them to the periphery of the cell (Fig. 2).

Many of the hepatocytes had signs of dystrophy. The cells became hypertrophic, changing their shape to more rounded in parallel with decreased basophilia and vacuolation of the cytoplasm with lipid inclusions. The greatest accumulation of lipids was observed in hepatocytes near the portal areas, with lipid vacuoles occurring both large and small in size. At predominantly macrovesicular vacuolation, the cytoplasm had an optically empty appearance, the nucleus shifted to the periphery of the cell (Fig. 3). The nature of the histological pattern of the liver tissue at 60 days of Feeding the Iron can be identified as steatohepatitis. Electron microscopic studies have shown that in experimental NASH (after 60 days of retention on HFD) significant changes in the plasma, nuclear and intracellular membranes of endothelial cells and hepatocytes develop in the liver against the background of microcirculation disturbance. Destabilization and destruction of cell membranes and organelle membranes adversely affect the metabolic and functional capacity of the organ [22].

The obtained results of a morphological study of the liver

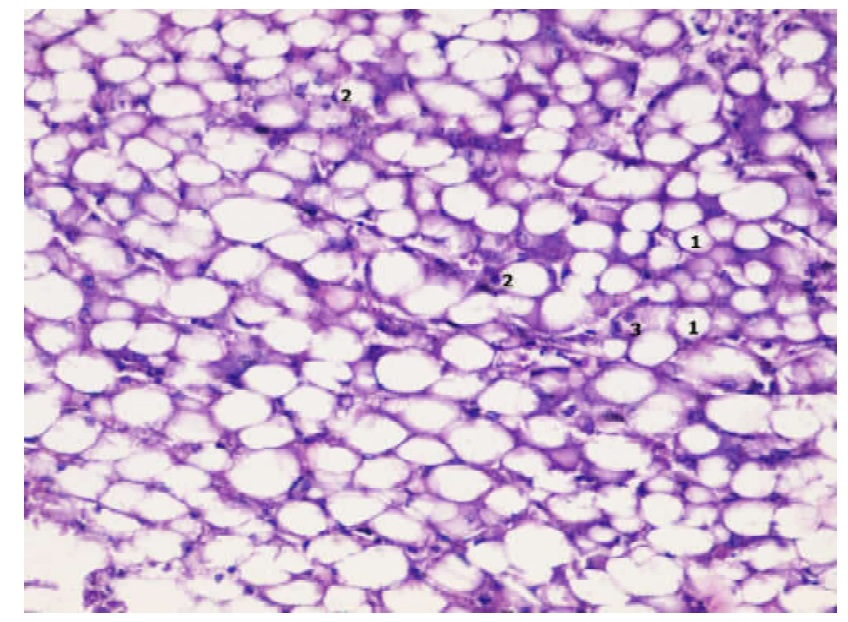

Fig. 2. The liver of the rat for 60 days of feeding the HFD. Diffuse mainly macrovesicular fatty degeneration of hepatocytes. Hematoxylin-eosin, x200. (1 - lipid droplets in the cytoplasm of hepatocytes, 2 - displacement of the hepatocyte nucleus to the periphery of the cell with a lipid droplet, 3 - dual-core hepatocytes).

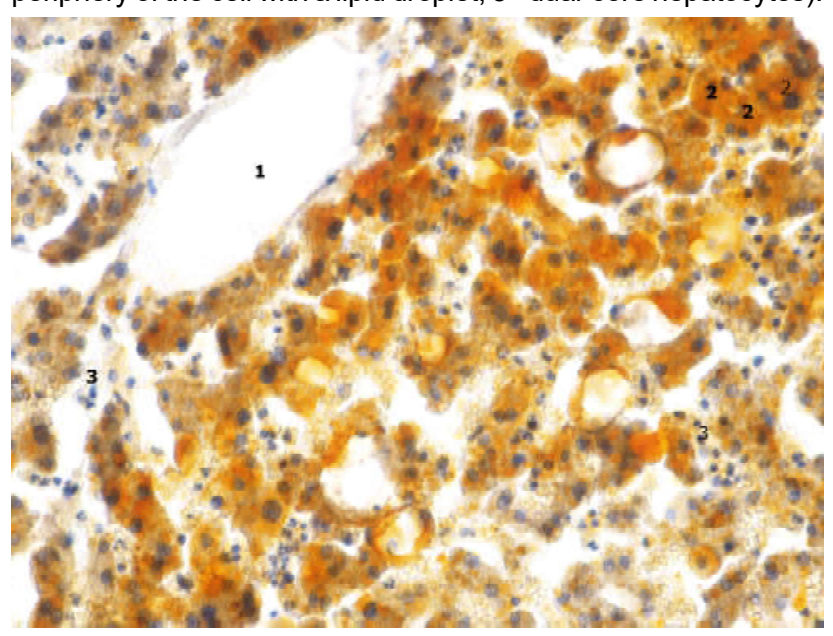

Fig. 3. The liver of the rat for 90 days of feeding the HFD. Preferably macrovesicular fatty degeneration of hepatocytes. Sudan III, x400. (1 - central vein, 2 - fat droplets of different sizes, 3 - sinusoidal hemocapillaries).

tissue of experimental animals with the NASH model on the background of the administration of the biologically active compound Angiolin at a dose of $50 \mathrm{mg} / \mathrm{kg}$ for a month indicated a partial restoration of the lobular structure of the liver parenchyma compared with animals with the NASH model without correction. The morphological structure of the liver was characterized by a decrease in fatty infiltration of hepatocytes, a partial restoration of the architectonics of hepatic beams, an increase in the number of binucleate hepatocytes (Fig. 4). However, hypertrophied hepatocytes and hepatocytes with focal fat inclusions in the cytoplasm were still detected.

We have studied the endothelial protective effect of the compound Angiolin. Our studies [23] of the submicroscopic state of animal liver endothelial cells in the correction of $\mathrm{NASH}$ by angiolin have established that the ultrastructural 


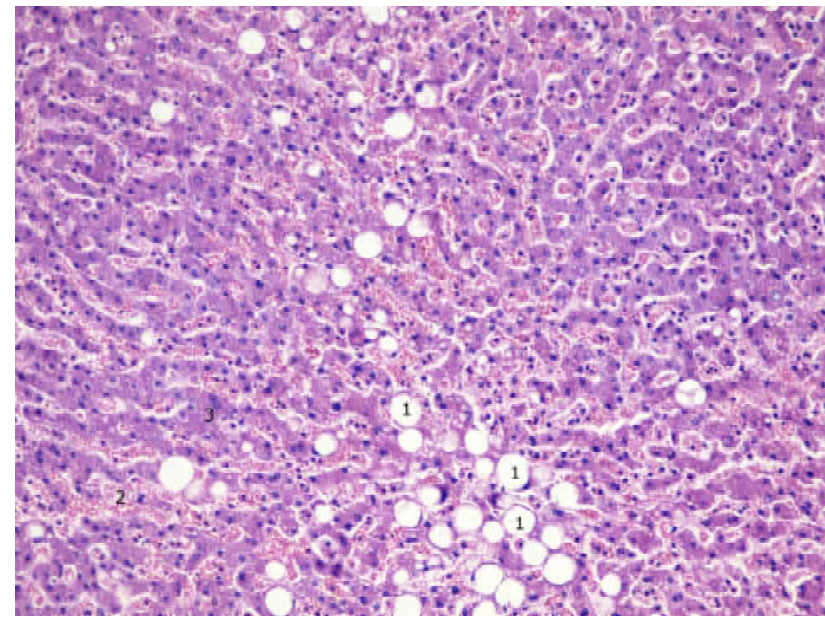

Fig. 4. Liver of the rat for 90 days of the experiment (60 days of feeding of HFD + application of Angiolin). Focal predominantly macrovascular fatty degeneration of hepatocytes. Hematoxylineosin, x200. (1 - lipid droplets in the cytoplasm of hepatocytes, 2 sinusoids, 3 - hypertrophied hepatocytes).

organization of endothelial cells has a typical long elongated shape. Elliptical nuclei include a karyoplasm made of euchromatin, which is confined to a karyolemma with clear nuclear membranes. Between them, there is a relatively uniform perinuclear space, and many nuclear pores are noted. The nuclear site of endothelial cell cytoplasm involves many small, small-sized organelles. The tubules of the granular endoplasmic reticulum and the enlightened matrix of individual mitochondria are somewhat enlarged. Narrow cytoplasmic sections of endothelial cells have well-defined perforations. Numerous microvilli are observed in Disse spaces and are well contoured.

\section{Discussion}

According to the literature [6], lipids contained in lipid droplets in the liver are dynamic and refer to metabolically active substances. Lipid droplets consist of the nucleus of triacylglycerols with or without cholesterol esters and the peripheral monolayer of phospholipids [24]. Inactive PNPLA3 has been shown to accumulate on the surface of lipid droplets and is associated with an increase in macrovesicular steatosis [25]. The inflammatory response

\section{References}

[1] Adams, L. A., Angulo, P., \& Lindor, K. D. (2005). Nonalcoholic fatty liver disease. CMAJ, 172(7), 899-905. doi: 10.1503/ cmaj.045232

[2] Anyanwu, G. O., Onyeneke, E. C., Usunobun, U., \& Adegbegi, A. J. (2013). Impact of Anthocleista vogelii root bark ethanolic extract on weight reduction in high carbohydrate diet induced obesity in male wistar rats. African Journal of Biochemistry Research, 7(11), 225-232. doi: 10.5897/AJBR2013.0692

[3] Arab, J. P., Arrese, M., \& Trauner, M. (2018). Recent insights into the pathogenesis of nonalcoholic fatty liver disease. Annual Review of Pathology: Mechanisms of Disease, 13, 321-350. doi: 10.1146 / annurev-pathol-020117-043617. does not always coincide with the prevalence of lipid droplets, indicating different mechanisms of lipid deposition and hepatocyte infiltration [26]. In addition, it is of interest to present a new theory that the trigger mechanism of hepatocyte dysfunction is lipotoxicity, which leads to disease progression in NASH. According to this theory, lipotoxic damage occurs under conditions of excessive movement of free fatty acids, especially saturated fatty acids, rather than through simple steatosis. It is likely that lipid accumulation occurs in parallel with the formation of lipotoxic metabolites, which are primarily responsible for the progression of liver disease and the development of insulin resistance [20].

According to the literature, liver cell damage and apoptosis are stimuli for the activation of mitogenic potential - liver cells on the background of steatosis / steatohepatitis are actively dividing and tend to accumulate less and less fat [1]. In the course of further evolution, apoptotic altered hepatocytes are transformed into small eosinophilic bodies of Counsilman [29]. Comparing the degree of reverse ultrastructural changes of endothelial cells and hepatocytes under the conditions of correction of the steatosis of the biologically active compound Angiolin at a dose of $50 \mathrm{mg}$ per $\mathrm{kg}$ of body weight and when applied for 4 weeks hepatoprotector ademetionin at a dose of $21 \mathrm{mg}$ per $\mathrm{kg}$ of body weight, damage to the structural components of the liver lobules. However, there are some differences. Thus, Angiolin correction showed better regeneration of sinusoidal hemocapillaries and hepatocytes and a better state of microvilli from the plasmolemma of the vascular section of hepatocytes.

In the future, it is promising to investigate the effect of Angiolin on the function of endothelial cells of the sinusoids of the liver and the secretion of biologically active substances produced by the endothelium.

\section{Conclusion}

The use of biologically active compound Angiolin once a day for 30 days allows to reduce cytolysis syndrome (to reduce biochemical parameters such as alanine aminotransferase activity, aspartate aminotransferase, gamma-glutamyltranspeptidase), reduce cholestasis syndrome (decrease in alkaline phosphatase level) hepatocytes, which will indicate the normalization of structural and functional state.

[4] Bahrii, M. M., Dibrova, V. A., Popadynets, O. H. \& Hryshchuk, M. I. (2016). Methods of morphological studies. Vinnytsia: New Book.

[5] Belenichev, I. F., Mazur, I. A., Abramov, A. V., Kucherenko, L. I., Bukhtiyarova, N. V., Egorov, A. A., ... \& Polyakova, E. N. (2013). The endothelium-protective effect of 3-methyl-1, 2, 4-triazolyl5-thioacetate (S)-2, 6-diaminohexanic acid (lysinium): Effects on the expression of vascular endothelial growth factor (VEGF) and the characteristics of the endotheliocytes of the cerebral vessels of animals with cerebral ischemia. Neurochemical journal, 7(4), 296-302.

[6] Benedict, M., \& Zhang, X. (2017). Non-alcoholic fatty liver 
disease: An expanded review. World J. Hepatol., 9(16), 715732. doi: 10.4254/wjh.v9.i16.715

[7] European Association for the Study of the Liver. (2016). Electronic address eee, European Association for the Study of D, European Association for the Study of O. EASL-EASDEASO Clinical Practice Guidelines for the management of nonalcoholic fatty liver disease. J. Hepatol., 64(6), 1388-1402. doi: 10.1016/j.jhep.2015.11.004

[8] Fan, J. G., Saibara, T., Chitturi, S., Kim, B. I., Sung, J. J., Chutaputti, A., \& Asia-Pacific Working Party for NAFLD. (2007). What are the risk factors and settings for non alcoholic fatty liver disease in Asia-Pacific? Journal of gastroenterology and hepatology, 22(6), 794-800. doi.org/10.1111/j.1440-1746.2007.04952.x

[9] Hamaguchi, M., Takeda, N., Kojima, T., Ohbora, A., Kato, T., Sarui, H., ... \& Takeda, J. (2012). Identification of individuals with non-alcoholic fatty liver disease by the diagnostic criteria for the metabolic syndrome. World journal of gastroenterology: WJG, 18(13), 1508-1516. doi: 10.3748/wjg.v18.i13.1508

[10] Hyogo, H., Chayama, K., Yamagishi, S. (2014). Nonalcoholic fatty liver disease and cardiovascular disease. Curr. Pharm. Des., 20(14), 2403-2411. doi: 10.2174/ 13816128113199990476

[11] Khukhlina, O. S., Antoniv, A. A., Kuzminska, O. B., Mandryk, O. Ye., \& Kotsiubiichuk, Z. Ya. (2018). Morphological features of the comorbid course of non-alcoholic steatohepatitis on the background of obesity and secondary arterial hypertension. Morphologia, 12(3), 140-145. doi.org/10.26641/19979665.2018.3.140-145

[12] Kucera, O., \& Cervinkova, Z. (2014). Experimental models of non-alcoholic fatty liver disease in rats. World $\mathrm{J}$. Gastroenterol., 20(26), 8364-8376. doi: 10.3748/ wjg.v20.i26.8364

[13] LaBrecque, D. R., Abbas, Z., Anania, F., Ferenci, P., Khan, A. G., Goh, K. L., ... \& Ramos, J. F. (2014). World Gastroenterology Organisation global guidelines: Nonalcoholic fatty liver disease and nonalcoholic steatohepatitis. Journal of clinical gastroenterology, 48(6), 467-473. doi: 10.1097/ MCG.0000000000000116

[14] Lazo, M., Hernaez, R., Bonekamp, S., Kamel, I. R., Brancati, F. L., Guallar, E., \& Clark, J. M. (2011). Non-alcoholic fatty liver disease and mortality among US adults: prospective cohort study. Bmj, 343, d6891. doi: https://doi.org/10.1136/bmj.d6891

[15] Lonardo, A., Nascimbeni, F., Mantovani, A., \& Targher, G. (2018). Hypertension, diabetes, atherosclerosis and NASH: cause or consequence? Journal of hepatology, 68(2), 335-352. doi: 10.1016/j.jhep.2017.09.021

[16] Lonardo, A., Nascimbeni, F., Maurantonio, M., Marrazzo, A., Rinaldi, L., \& Adinolfi, L. E. (2017). Nonalcoholic fatty liver disease: Evolving paradigms. World Journal of gastroenterology, 23(36), 6571-6592. doi: 10.3748/ wjg.v23.i36.6571

[17] Motamed, N., Rabiee, B., Poustchi, H., Dehestani, B., Hemasi, G. R., Khonsari, M. R., ... \& Zamani, F. (2017). Non-alcoholic fatty liver disease (NAFLD) and 10-year risk of cardiovascular diseases. Clinics and research in hepatology and gastroenterology, 41(1), 31-38. doi.org/10.1016/ j.clinre.2016.07.005

[18] Nagornaya, E. A., Belenichev, I. F., Gorchakova, N. A., Mazur, I. A., \& Chekman, I. S. (2017). Angiolon Influence on the Morphofunctional Characteristics of Rats' Endotheliocytes in Chronic Cardiac Insufficiency. Ukrainian Journal of Medicine, Biology and Sport, 3(5), 21-25. doi: 10.26693/jmbs02.03.021

[19] Novelli, E. L. B., Diniz, Y. S., Galhardi, C. M., Ebaid, G. M. X., Rodrigues, H. G., Mani, F., ... \& Novelli Filho, J. L. V. B. (2007). Anthropometrical parameters and markers of obesity in rats. Laboratory animals, 41(1), 111-119.

[20] Peverill, W., Powell, L., \& Skoien, R. (2014). Evolving concepts in the pathogenesis of NASH: beyond steatosis and inflammation. International journal of molecular sciences, 15(5), 8591-8638. doi: 10.3390/ijms 15058591

[21] Pivtorak, K. V. (2015). Submicroscopic State of the Liver in the Correction of Steatosis Using the Hepatoprotector of Amino Acid Origin. Bulletin of problems in Biology and Medicine, 3 , 2(123), 310-313.

[22] Pivtorak, K. V. (2015). Submicroscopic changes in experimental hepatic steatosis. Visnyk morfologii, 21(1), 69-72.

[23] Pivtorak, K. V., Mazur, I. A., \& Voloshyn, M. A. (2015). The ultrastructure of endothelial cells of hepatic steatosis in the correction of new biologically active compound Angiolin. Pathology, 12(3), 49-52. doi: http://dx.doi.org/10.14739/23101237.2015.3.55587

[24] Sahini, N., \& Borlak, J. (2014). Recent insights into the molecular pathophysiology of lipid droplet formation in hepatocytes. Progress in lipid research, 54, 86-112. doi: 10.1016/ j.plipres.2014.02.002

[25] Smagris, E., BasuRay, S., Li, J., Huang, Y., Ka?man, V. L., Gromada, J., Cohen, J.C. \& Hobbs, H. H. (2015). Pnpla3I148M knockin mice accumulate PNPLA3 on lipid droplets and develop hepatic steatosis. Hepatology, 61(1), 108-118. doi: 10.1002/ hep. 27242

[26] Stepanov, Yu. M., Gaidar, Yu. A., Didenko, V. I., Oshmianskaia, N. Yu., \& Arzhanova, G. Yu. (2016). Morphological differentiation of hepatic steatosis in patients with alcoholic and non-alcoholic hepatitis. Journal of the National Academy of Medical Sciences of Ukraine, 22(3-4), 359-367.

[27] Tajiri, K., \& Shimizu, Y. (2012). Role of NKT cells in the pathogenesis of NAFLD. International journal of hepatology, 2012. doi: $10.1155 / 2012 / 850836$

[28] Takahashi, Y., Soejima, Y., \& Fukusato, T. (2012). Animal models of nonalcoholic fatty liver disease/nonalcoholic steatohepatitis. World J. Gastroenterol., 18(19), 2300-2308. doi: 10.3748/ wjg.v18.i19.2300

[29] Tumansky, V. A., Fen', S. V., \& Tumanskaya, L. M. (2017). Pathomorphological analysis of adverse effects of nonalcoholic and alcoholic steatohepatitis. Morphologia, 11(4), $59-74$.

\section{ОСОБЛИВОСТІ СТРУКТУРНИХ ТА ФУНКЦІОНАЛЬНИХ ПАРАМЕТРІВ ПЕЧІНКИ ЗА УМОВ ЕКСПЕРИМЕНТАЛЬНОГО СТЕАТОГЕПАТИТУ ТА ЙОГО КОРЕКЦІЇ У ЩУРІВ 3 ОЖИРІННЯМ \\ Півторак К.В.}

Удосконалення фрармакологічної стратегії неалкогольної жирової хвороби печінки основано на вивченні впливу фрармпрепаратів на структуру та функцію печінки. Патогенез неалкогольного стеатогепатиту $є$ складним $i$ багатофракторним, в основному за участю генетичних, метаболічних фракторів і факторів навколишнього середовища. Мета дослідження - охарактеризувати структурні та функціональні параметри печінки при корекції експериментального стеатогепатиту біологічно активною сполукою Ангіолін. Експериментальне дослідження виконано на 110 статевозрілих білих щурах-самиях масою 180-220 грамів, котрих утримували на стандартному раціоні віварію. Усіх тварин розподілили 
на 2 групи: контрольну (30 інтактних тварин) та дослідну (80 тварин). Усім тваринам дослідної групи створювали модель неалкогольного стеатогепатиту, для чого протягом 8 тижнів утримували на гіперкалорійній дієті з високим вмістом жирів та холестерину. Частину тварин (10 щурів) виводили з досліду шляхом внутрішньо-плеврального введення тіопенталунатрію (50 мг/кг) та проводили необхідні біохімічні та морфологічні дослідження, частину тварин (30 щурів) ще протягом 4 тижнів продовжували утримувати на високожировій дієті та вводили біологічно активну сполуку Ангіолін (20 щурів), а 10 щурам лище розчин Рінгера-Локка. Інших тварин дослідної групи (40 щурів) після створення моделі перевели на повноцінну стандартну напівсинтетичну крохмально-казеїнову дієту та протягом 4 тижнів вводили (20 щурів) біологічно активну сполуку Ангіолін, а 20 щурам лише розчин Рінгера-Локка. Макроскопічну оцінку та описання печінки тварин проводили після вилучення тварин із експерименту під тіопенталовим наркозом. Статистичний аналіз отриманих результатів проведений у програмі "STATISTICA 8" з використанням параметричних і непараметричних методів оцінки отриманих результатів. Встановлено, що застосування Ангіоліну 1 раз на добу протягом 30 днів дозволяє зменшити синдром цитолізу (знижується активність аланінамінотрансферази, аспартатамінотрансферази, гамма-елутамілтранспептидази), зменшити синдром холестазу (рівень лужної фоссратази зменшується), покращити морфологічний стан гепатоцитів та нормалізувати функцію печінки.

Ключові слова: хвороби печінки, стеатогепатит, моделювання, морфологія, корекція.

\section{ОСОБЕННОСТИ СТРУКТУРНЫХ И ФУНКЦИОНАЛЬНЫХ ПАРАМЕТРОВ ПЕЧЕНИ В УСЛОВИЯХ ЭКСПЕРИМЕНТАЛЬНОГО СТЕАТОГЕПАТИТА И ЕГО КОРРЕКЦИИ У КРЫС С ОЖИРЕНИЕМ Пивторак Е.В.}

Усовершенствование фрармакологической стратегии неалкогольной жировой болезни печени основано на изучении влияния фрармпрепаратов на структуру и функцию печени. Патогенез стеатогепатита является сложным и многофакторным, 8 основном с участием генетических, метаболических фракторов и фракторов окружающей среды. Цель исследования охарактеризовать структурные и функциональные параметры печени при коррекции экспериментального стеатогепатита биологически активным соединением Ангиолина. Экспериментальное исследование выполнено на 110 половозрелых белых крысах-самцах массой 180-220 граммов, которых содержали на стандартном рационе вивария. Всех животных разделили на две группы: контрольную (30 интактных животных) и опытную (80 животных). Всем животным опытной группы создавали модель неалкогольного стеатогепатита, для чего в течение 8 недель удерживали на гиперкалорийной диете $c$ высоким содержанием жиров и холестерина. Часть животных (10 крыс) выводили из опыта путем внутриплеврального введения тиопентала натрия (50 мг/кг) и проводили необходимые биохимические и морфологические исследования, часть животных (30 крыс) еще в течение 4 недель продолжали удерживать на высокожировой диете и 20 крысам вводили биологически активное соединение Ангиолина, а 10 крысам только раствор Рингера-Локка. Других животных опытной группы (40 крыс) после создания модели перевели в полноценную стандартную полусинтетическую крахмало-казеиновую диету и в течение 4 недель вводили (20 крыс) биологически активное соединение Ангиолина, а 20 крысам только раствор Рингера-Локка. Макроскопическая оценка и описание печени животных проводилось после выведения животного из эксперимента под тиопенталовым наркозом. Статистический анализ полученных результатов проведен в программе "STATISTICA 8" с использованием параметрических и непараметрических методов оценки полученных результатов. Установлено, что применение Ангиолина 1 раз в сутки в течение 30 дней позволяет уменьшить синдром цитолиза (снижается активность АЛТ, АСТ, гамма-глутамилтранспептидазы), уменьшить синдром холестаза (уровень щелочной фоссратазы снижается), улучшить морфологическое состояние гепатоцитов и нормализовать функцию печени. Ключевые слова: болезни печени, стеатогепатит, моделирование, морфология, коррекция. 